\title{
Festschrift on Diabetic Eye Disease in Honor of Prof. José Cunha-Vaz
}

\author{
Hendrik P.N. Scholla-c \\ ${ }^{a}$ Institute of Molecular and Clinical Ophthalmology Basel (IOB), Basel, Switzerland; ${ }^{b}$ Department of Ophthalmology, \\ University of Basel, Universitätsspital Basel, Basel, Switzerland; ' Wilmer Eye Institute, Johns Hopkins University, \\ Baltimore, MD, USA
}

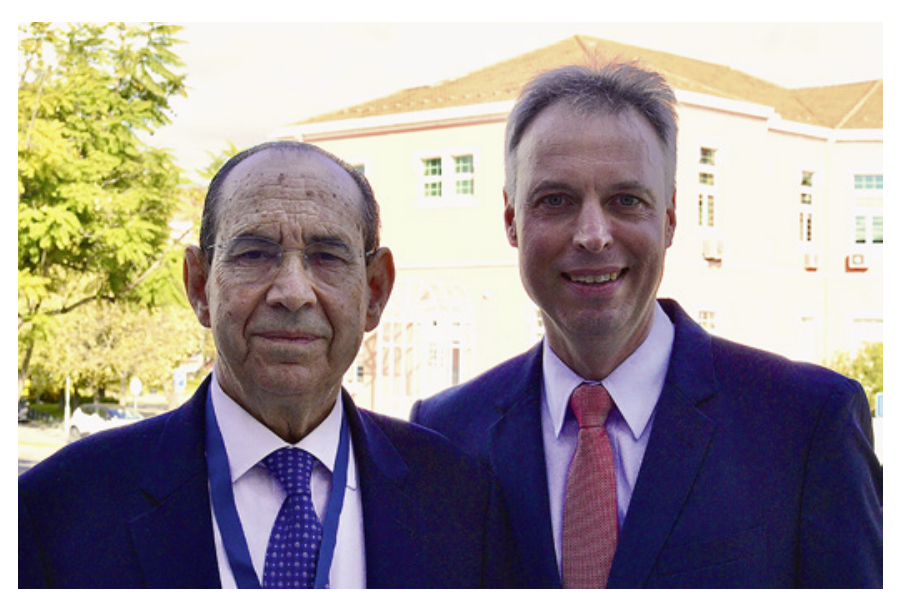

Drs. José Cunha-Vaz and Hendrik Scholl at the 14th EVICR.net Annual Members Meeting, Oct. 24-25, 2019, at INFARMED, the National Authority of Medicines and Health Products, Lisbon, Portugal.

This Festschrift honors José Cunha-Vaz, MD, PhD, who has led ground-breaking basic science and clinical research on vascular retinal disease, particularly diabetic eye disease. It is a special issue of the peer-reviewed journal Ophthalmic Research and includes a collection of essays authored by eminent scientists on diabetic retinopathy (DR) and diabetic macular edema (DME). Topics include the gold standard of grading DR by the Early Treatment of Diabetic Retinopathy Study (ETDRS)

\section{KARGER}

() 2019 S. Karger AG, Basel

E-Mail karger@karger.com

www.karger.com/ore group, the pathophysiology of DR, the characterization of the initial stages of DME, DR within the spectrum of diabetic complications, screening approaches for DR, contributions of the Diabetic Retinopathy Clinical Research Network (DRCR.net) to the treatment of DR, and the role of steroids for treating DME.

Dr. Cunha-Vaz is Emeritus Professor of Ophthalmology of the University of Coimbra, Portugal, and President of the Association for Innovation and Biomedical Research on Light and Image (AIBILI). He was the ninth Editor-inChief of Ophthalmic Research and is now Honorary Editor. $\mathrm{He}$ is also the Diabetic Retinopathy and Vascular Diseases Expert Committee Coordinator of the European Vision Institute Clinical Research Network (EVICR.net) [1].

Dr. Cunha-Vaz became Chair and Director of the Department of Ophthalmology at the University of Coimbra in 1972 . He moved to the USA in 1979 to become a fulltime Professor of Ophthalmology and Director of the Retina Service at the University of Illinois at Chicago until his final return to Portugal in 1986. He returned to his original position where he led the department until 2008. In 1994, he became the founding director of the Institute of Biomedical Research on Light and Image (IBILI), a large institute dedicated to vision research, and of AIBILI, a nonprofit clinical research center.

His work includes laboratory and clinical research in retina and intraocular fluids with a special emphasis on bloodretinal barriers and DR. He was the first to identify the anatomical basis of the blood-retinal barrier [2], tight junctions 
in retinal vessels [3], and an active transport system in retinal vessels and retinal pigment epithelium [4]. He later introduced the concept of multimodal macula mapping [5] and identified different phenotypes of non-proliferative DR in type 2 diabetes [6]. Dr. Cunha-Vaz and his group identified microaneurysm turnover as a biomarker for DR progression towards clinically significant DME [7]. Recently, he has played a pivotal role in the development of OCT leakage as a new method to identify and locate abnormal fluid accumulation in diabetic retinal edema [8].

Dr. Cunha-Vaz has authored and co-authored over 500 peer-reviewed papers and books. He was elected member of the Academia Ophthalmologica Internationalis (1995). Amongst his many honors and awards are the Paul Henkind Memorial Award and Lecture by the
Macula Society (1998), the Alcon Research Institute Award (1998), the Helmholtz Gold Medal by the European Society of Ophthalmology (2007), and the Weisenfeld Award by the Association for Research in Vision and Ophthalmology (2016) $[9,10]$.

Amongst the dozens of named lectures is the inaugural José Cunha-Vaz Lectureship, named for him in 2008 by the Portuguese Society of Ophthalmology, of which he is also an elected honorary member. Furthermore, he is past president of the European Society of Retinal Specialists/ EURETINA, the European Society for Cataract and Refractive Surgeons, and the European University Professors of Ophthalmology. The Portuguese government awarded him its highest civilian honor, the King Henry the Navigator Medal.

\section{References}

1 Martinho CV, Sanches Fernandes D. European Network of Clinical Research in Ophthalmology information update - December 2018. Ophthalmic Res. 2019;61(4):183-7.

2 Cunha-Vaz JG, Shakib M, Ashton N. Studies on the permeability of the blood-retinal barrier. I. On the existence, development, and site of a blood-retinal barrier. Br J Ophthalmol. 1966 Aug;50(8):441-53.

3 Shakib M, Cunha-Vaz JG. Studies on the permeability of the blood-retinal barrier. IV. Junctional complexes of the retinal vessels and their role in the permeability of the blood-retinal barrier. Exp Eye Res. 1966 Jul;5(3):229-34.

4 Cunha-Vaz JG, Maurice DM. The active transport of fluorescein by the retinal vessels and the retina. J Physiol. 1967 Aug;191(3): $467-86$.
5 Bernardes R, Lobo C, Cunha-Vaz JG. Multimodal macula mapping: a new approach to study diseases of the macula. Surv Ophthalmol. 2002 Nov-Dec;47(6):580-9.

6 Lobo CL, Bernardes RC, Figueira JP, de Abreu JR, Cunha-Vaz JG. Three-year follow-up study of blood-retinal barrier and retinal thickness alterations in patients with type 2 diabetes mellitus and mild nonproliferative diabetic retinopathy. Arch Ophthalmol. 2004 Feb;122(2):211-7.

7 Nunes S, Pires I, Rosa A, Duarte L, Bernardes $\mathrm{R}$, Cunha-Vaz J. Microaneurysm turnover is a biomarker for diabetic retinopathy progression to clinically significant macular edema: findings for type 2 diabetics with nonproliferative retinopathy. Ophthalmologica. 2009; 223(5):292-7.
8 Cunha-Vaz J, Santos T, Ribeiro L, Alves D, Marques I, Goldberg M. OCT-Leakage: A New Method to Identify and Locate Abnormal Fluid Accumulation in Diabetic Retinal Edema. Invest Ophthalmol Vis Sci. 2016 Dec; 57(15):6776-83.

9 Cunha-Vaz J. Phenotypes and biomarkers of diabetic retinopathy. Personalized medicine for diabetic retinopathy: the Weisenfeld award. Invest Ophthalmol Vis Sci. 2014 Aug; 55(8):5412-9.

10 Goldberg MF. Introducing José Cunha-Vaz, the 2014 recipient of the Weisenfeld award. Invest Ophthalmol Vis Sci. 2014 Aug;55(8): 5410-1. 